\title{
Wystąpienie Krzysztofa Rączki, Dziekana Wydziału Prawa i Administracji UW
}

Jest mi niezwykle miło, że możemy tutaj spotkać się dzisiaj, aby uczcić pamięć i dorobek naukowy Pana Profesora Andrzeja Stelmachowskiego, który bez wątpienia był jednym z najwybitniejszych profesorów naszego Wydziału. Jednym z najwybitniejszych przedstawicieli nauki prawa w Polsce. Pan Profesor Andrzej Stelmachowski był aktywny na wielu forach, poza pracą naukową, poza pracą dydaktyczną, był wielkim społecznikiem, był politykiem, był Mężem Stanu. Bez wątpienia, to miejsce, Uniwersytet Warszawski, był dla Niego najważniejszym miejscem w życiu, co często podkreślał, co w naszych rozmowach się przewijało. Niezależnie od tego co robił w życiu, to Uniwersytet był tym najważniejszym miejscem, nauka była tym, czemu poświęcił się w swoim dorosłym życiu.

Profesor przez całe życie był związany ze środowiskiem akademickim. Najpierw z Uniwersytetem im. Adama Mickiewicza w Poznaniu, później z Uniwersytetem Warszawskim, następnie z Uniwersytetem Wrocławskim, by powrócić na Uniwersytet Warszawski. Te koleje losu Profesora były bardzo burzliwe, co bez wątpienia związane było z Jego niepokorną osobowością. Bo to, że był człowiekiem niepokornym, to nie budziło wątpliwości. Był nonkonformistą. Zawsze chadzał własnymi drogami, tak w życiu społecznym, politycznym, jak i życiu naukowym.

Pozwólcie Państwo, że przytoczę taką anegdotę. Kiedyś pytałem się Profesora: Panie Profesorze, dlaczego Pan Profesor jest tak często cytowany? A Profesor odpowiedział: Panie kolego, bo w życiu trzeba głosić właśnie nonkonformistyczne poglądy i wtedy wszyscy będą czuli się w obowiązku, żeby z Panem polemizować.

Profesor miał ogromne poczucie humoru, takie zdystansowane poczucie humoru i zdystansowany stosunek do siebie. Takiego Profesora Stelmachowskiego zapamiętałem. Nie budzi wątpliwości, że Profesor Andrzej Stelmachowski ,wielkim uczonym był". To jest poza wszelką dyskusją. Miał ogromny, wszechstronny dorobek naukowy. Zajmował się takimi dziedzinami, jak teoria prawa, prawo cywilne, prawo administracyjne, a przede wszystkim prawo rolne. Profesor Stelmachowski był twórcą szkoły prawa rolnego w Polsce. Potrafił wokół siebie zgromadzić bardzo wielu wybitnych przedstawicieli świata prawniczego. Potrafił ogniskować zainteresowanie wokół prawa rolnego.

Pamiętam, że jak zaczynałem pracę na Uniwersytecie, to kupiłem sobie „Wstęp do teorii prawa cywilnego". Do dzisiaj ta książka stoi w pierwszym szeregu książek w mojej bibliotece. Mimo iż tyle lat upłynęło, to ona jest ciągle w pierwszym 
szeregu i ciągle do niej w niektórych momentach zaglądam. To świadczy o tym, że ten dorobek Profesora Stelmachowskiego jest dorobkiem, który nie przemija. Stan prawny się zmienia, ale pewne myśli, pewne koncepcje pozostają. Mam nadzieję, że w tych dyskusjach, które będą się toczyły, te myśli Profesora będą często przywoływane.

I jeszcze jedna sprawa, którą chciałem podkreślić. Profesor Stelmachowski był wymagającym, ale bardzo wybitnym nauczycielem. Wymagał przede wszystkim od siebie, ale wymagał także od studentów, później od swoich uczniów. Pozwólcie Państwo, że wspomnę taki moment na pogrzebie Pana Profesora, gdy na cmentarzu podeszła do mnie Pani Profesor Korzycka i powiedziała: „Jak będziesz mówił o Panu Profesorze, to powiedz kilka słów także od nas”. Ponieważ ceremoniał był taki, że wystąpienia były limitowane, także uczniowie Pana Profesora poprosili mnie, abym powiedział parę słów od nich. Właśnie takich słów od serca. Wydaje mi się, że dzisiaj uczniowie Pana Profesora też będą wspominać swoje kontakty z Panem Profesorem i Jego wpływ na ich rozwój naukowy i osobisty.

Życzę Państwu owocnej dyskusji i owocnych obrad. Wspominajmy Pana Profesora, bo póty żyjemy, póki jesteśmy w myślach innych ludzi. 